\title{
A morphophysiological conception and model of animal growth
}

\author{
G.G. Cherepanov \\ Institute of Physiology, Biochemistry and Nutrition of Farm Animals, \\ Russian Academy of Agricultural Sciences \\ Borovsk-3, Kaluga Region, 249013, Russia
}

(Received I February 2001; accepted 7 August 2001)

\section{ABSTRACT}

On the basis of previously validated biological concepts, a model of postnatal growth in livestock is proposed. It postulates the existence of two leading processes, ccll proliferation in growth plates of bones and nuclei multiplication in skeletal muscle tissue, and surmises that the basic kinetic parameters of RNA and protein metabolism in cross-striated muscles remain steady (relatively constant) throughout the period from the early postnatal stage to maturity.

The weight of skeletal muscle tissue is predicted on the basis of a dynamic sub-model and the weights of the skeleton, carcass and live body are calculated using regression relationships. When applied to farm animals, the model adequately fit experimental data and predicted that each biological type and separate group of animals (brecd, sex, line, etc.) has an optimal zone of growth intensity with the most effective transformation of food into body components. We conclude by sketching directions for future work, and suggesting some possible practical implications.

KEY WORDS: muscle, bone, livestock, model, growth curve

\section{INTRODUCTION}

Livestock production is in urgent need of animals with optimal quantitative traits in the sense of production efficiency. Progress in biotechnology provides (or will provide in the nearest future) an opportunity to modify local cell parameters with the aim of constructing animals with programmed quantitative traits (augmented growth, hypertrophied musculature, decreased fatness, etc). These projects need instruments for theoretical screening of modified phenotype variants to pre- 
dict performance and to test alternative feeding or management strategies for new types of animals.

Dynamic models of growth in rats and steers have been described previously based explicitly on concepts of hyperplasia (DNA synthesis) and hypertrophy (protein accretion) at the level of the whole organism (Oltjen et al., 1986; Soboleva et al., 1999). Although the models did fit the experimental data, they were considered appropriate only as a first step in achieving the aims of a long-term program on modeling mammalian growth. Here we describe a more detailed concept with special focus on the development of the skeletal-muscular system and inter-organ interactions during postnatal growth in mammals. Growth curves predicted by the model are compared with relevant empirical data. Some prospective areas of applying the theory to animal science are discussed.

\section{A MORPHOPHYSIOLOGICAL CONCEPT OF POSTNATAL GROWTH}

Taking into account empirical facts and interrelationships observed during the growth of bones (Kember, 1982) and muscles (Burleigh, 1974; Swatland, 1977; Allen et al., 1979; Campion et al., 1981, 1987) the following cause-and-effect chain of the main events in the course of animal growth can be suggested. The division of cells in the epiphyseal cartilage (with subsequent elongation of myofibres) and proliferation of satellite cells lead in the long run to the formation of myofibres of a finite length with a finite total pool of myonuclei. The number of ribosomes in the myofibres at any given moment is determined by the balance of ribosome formation and degradation of ribosomal subunits. Similarly, the total protein pool in myofibres depends on the functional activity of ribosomes and on the stability of muscle proteins (Alberghina, 1975; Bates and Millward, 1981). The total weight of the skeleton depends on bone length and on compressional load which, on the other hand, relates to muscle mass. The weight of the fat depot depends on age and level of nutrition. The sum of the muscle, skeleton and fat depot weights is the weight of the carcass which is the main component of liveweight (Figure 1).

\section{MODEL}

Taking into account the vast diversity of histological types, macro- and microstructure, rates of allometric growth and of anatomical sizes of striated muscles, let us consider a model striated muscle grown with an allometric coefficient of $\mathrm{m}=1$ and with average values of structural and functional parameters. One diploid nucleus of a myofiber contains 6.2 pg of DNA (Cheek and Hill, 1971), therefore, the total DNA content of the model muscle $\left(\mathrm{D}^{\wedge}, \mathrm{g}\right)$ is: 


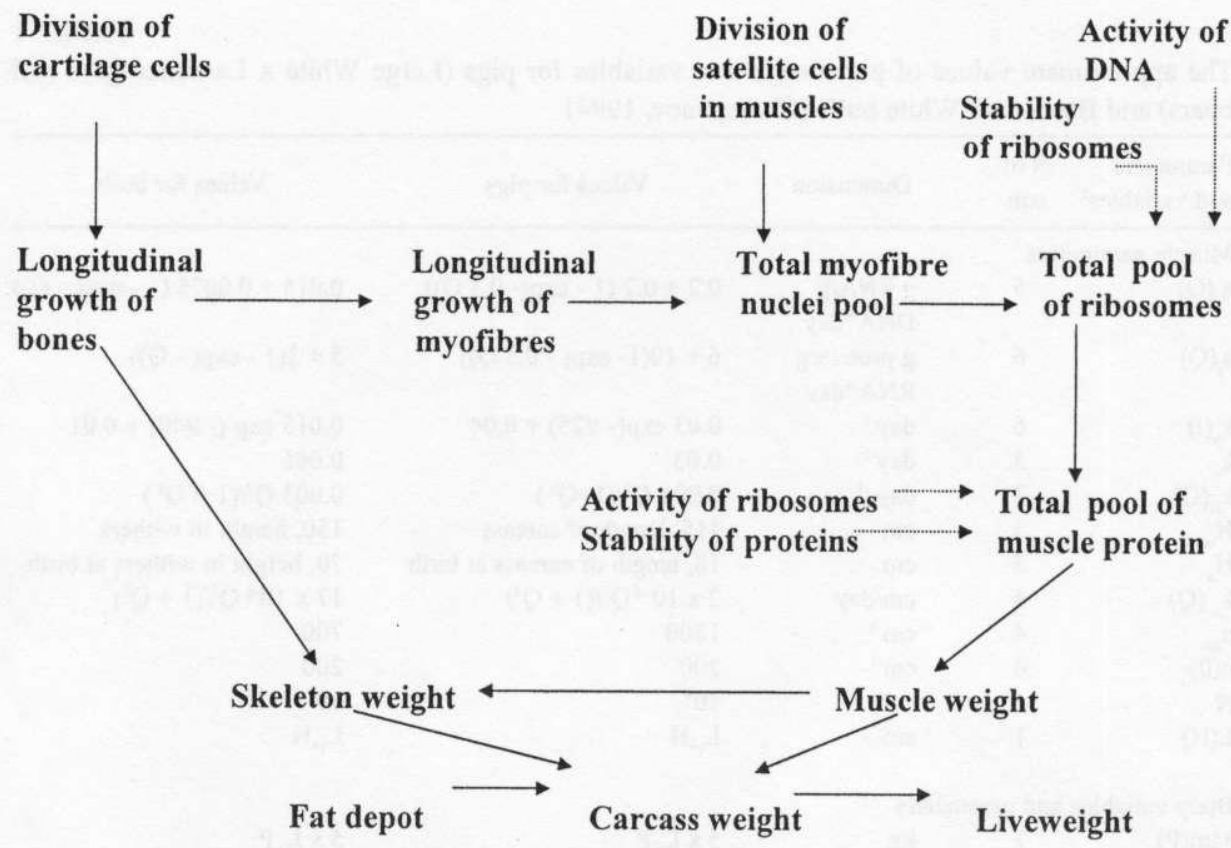

Figure 1. Schematic representation of morphophysiological conception of animal growth. The solid arrows indicate the cause-and-consequence relationships, dotted arrows indicate the effects of local cell parameters

$$
\mathrm{D}^{\wedge}=6.2 \cdot 10^{-12} \mathrm{n} \mathrm{L} \mathrm{N},
$$

where $\mathrm{n}$ is the mean number of myofibre nuclei per unit of myofibre length $\left(\mathrm{cm}^{-1}\right)$; $\mathrm{L}$ is the mean length of myofibres $(\mathrm{cm}) ; \mathrm{N}$ is the number of myofibres in the model muscle.

Based on the foregoing arguments, the mean length of myofibres in the model muscle $(\mathrm{L}, \mathrm{cm})$ can be put in relation to some characteristic size of the skeleton (height in withers, length of carcass etc) $\mathrm{H}(\mathrm{cm})$ :

$$
\mathrm{L}=\mathrm{L}_{1} \times \mathrm{H},
$$

where $\mathrm{L}_{1}$ is a coefficient (Table 1 ).

According to available data, longitudinal growth of the skeleton in most species can be approximated by the equation:

$$
\mathrm{dH} / \mathrm{dt}=\mathrm{k}_{\mathrm{H}}(\mathrm{Q})\left(\mathrm{H}_{\mathrm{oo}}-\mathrm{H}\right),
$$

where $\mathrm{H}_{\mathrm{oo}}$ is a characteristic dimension of the skeleton in the mature animal $(\mathrm{cm}) ; \mathrm{k}_{\mathrm{H}}$ is the fractional linear growth coefficient (1/day) as a function of the 
TABLE 1

The approximate values of parameters and variables for pigs (Large White $\mathrm{x}$ Landrace gilts and boars) and Black-and-White bulls (Cherepanov, 1994)

\begin{tabular}{|c|c|c|c|c|}
\hline $\begin{array}{l}\text { Parameters } \\
\text { and variables }\end{array}$ & $\begin{array}{l}N \text { of } \\
\text { eqn }\end{array}$ & Dimension & Values for pigs & Values for bulls \\
\hline \multicolumn{5}{|c|}{ Muscle parameters } \\
\hline$a_{d}(Q)$ & 5 & $\begin{array}{l}\text { g RNA/g } \\
\text { DNA*day }\end{array}$ & $0.2+0.2(1-\exp (-0.3 \mathrm{Q}))$ & $0.015+0.0075(1-\exp (-Q))$ \\
\hline$a_{r}(Q)$ & 6 & $\begin{array}{l}\text { g protein/g } \\
\text { RNA*day }\end{array}$ & $6+10(1-\exp (-0.3 \mathrm{Q}))$ & $5+3(1-\exp (-Q))$ \\
\hline$k_{p}(t)$ & 6 & day $^{-1}$ & $0.03 \exp (-t / 25)+0.04$ & $0.015 \exp (-t / 40)+0.01$ \\
\hline$k_{r}$ & 5 & day $^{-1}$ & 0.03 & 0.006 \\
\hline $\mathrm{k}_{\mathrm{H}}(\mathrm{Q})$ & 3 & day $^{-1}$ & $0.006 \mathrm{Q}^{2} /\left(1+\mathrm{Q}^{2}\right)$ & $0.003 \mathrm{Q}^{2} /\left(1+\mathrm{Q}^{2}\right)$ \\
\hline $\mathrm{H}_{o}$ & 3 & $\mathrm{~cm}$ & 115 , length of carcass & 150 , height in withers \\
\hline $\mathrm{H}_{\mathrm{o}}$ & 3 & $\mathrm{~cm}$ & 18 , length of carcass at birth & 70 , height in withers at birth \\
\hline$k_{n}(Q)$ & 4 & $\mathrm{~cm} /$ day & $2 \times 10^{-5} Q^{3} /\left(1+Q^{3}\right)$ & $17 \times 10^{-6} \mathrm{Q}^{3} /\left(1+\mathrm{Q}^{3}\right)$ \\
\hline $\mathrm{n}_{\mathrm{oo}}$ & 4 & $\mathrm{~cm}^{-1}$ & 1200 & 700 \\
\hline $\mathrm{n}(0)$ & 4 & $\mathrm{~cm}^{-1}$ & 200 & 200 \\
\hline $\mathrm{N}$ & 1 & & $10^{6}$ & $10^{7}$ \\
\hline $\mathrm{L}(\mathrm{H})$ & 1 & $\mathrm{~cm}$ & $\mathrm{~L}_{1} \cdot \mathrm{H}$ & $\mathrm{L}_{1} \cdot \mathrm{H}$ \\
\hline \multicolumn{5}{|c|}{ Body variables and parameters } \\
\hline $\operatorname{Mm}(\mathrm{P})$ & 7 & $\mathrm{~kg}$ & $5 \times \mathrm{L}_{3} \mathrm{P}$ & $5 \times \mathrm{L}_{3} \mathrm{P}$ \\
\hline $\mathrm{Ms}(\mathrm{H}, \mathrm{Mm})$ & 8 & $\mathrm{~kg}$ & $\mathrm{~L}_{4} \mathrm{H} \mathrm{Mm}^{\mathrm{b}}$ & $\mathrm{L}_{4} \mathrm{HMm}^{\mathrm{b}}$ \\
\hline $\mathrm{W}(\mathrm{Mc})$ & & $\mathrm{kg}$ & $1012-1024 \exp (-0,003 \mathrm{Mc})$ & $350(1-\exp (-0.0065 \mathrm{Mc}))$ \\
\hline Wo(W) & & $\mathrm{kg}$ & $0.95 \mathrm{~W}$ & $13,27+0,7 \mathrm{~W}+0.00021 \mathrm{~W}^{2}$ \\
\hline $\mathrm{df} / \mathrm{d} t$ & 10 & $\% /$ day & $\begin{array}{l}\mathrm{L}_{6}(1+4 \mathrm{Q}) \mathrm{f} \ln \left(\mathrm{f}_{\mathrm{oo}} / \mathrm{f}\right) \\
\mathrm{f}_{\mathrm{oo}}=50 \\
\mathrm{f}(0)=1\end{array}$ & $\begin{array}{l}L_{6} Q f\left(f_{o o}-f\right) \\
f_{o o}=40 \\
f(0)=3\end{array}$ \\
\hline B & 8 & & 0.6 & 0.5 \\
\hline $\mathrm{L}_{1}$ & 2 & & 0.56 & 0.133 \\
\hline $\mathrm{L}_{3}$ & 7 & & 0.018 & 0.0287 \\
\hline $\mathrm{L}_{4}$ & 8 & & 0.012 & 0.031 \\
\hline $\mathrm{L}_{6}$ & & & $10^{-3}$ & $85 \times \times 10^{-6}$ \\
\hline $\mathrm{L}_{7}$ & 11 & & 0.01 & 0.01 \\
\hline $\mathrm{L}_{8}$ & 12 & & 0.7 & 0.295 \\
\hline
\end{tabular}

'see the text for explanation of symbols

energy variable, $\mathrm{Q}$. Input variable $\mathrm{Q}$ can be approximated as $\mathrm{Q}=(\mathrm{E} / \mathrm{Em})-1$, where $\mathrm{E}$ is metabolizable energy (ME), Em is ME required for maintenance.

The linear concentration of myofibre nuclei in the model muscle $\mathrm{n},\left(\mathrm{cm}^{-1}\right)$, as a function of age, can be approximated by some curve achieving a plateau at maturity (Campion, 1981). The daily increment of $n$ depends upon the level of nutrition (Swatland, 1977). Such a curve can be approximated, for example, by the solution to the following equation:

$$
\mathrm{dn} / \mathrm{dt}=\mathrm{k}_{\mathrm{n}}(\mathrm{Q})\left(\mathrm{n}_{\mathrm{oo}}-\mathrm{n}\right) \mathrm{n},
$$


where $\mathrm{k}_{\mathrm{n}}\left(\mathrm{cm} /\right.$ day) is a growth coefficient as a function of $\mathrm{Q} ; \mathrm{n}_{\mathrm{oo}}$ is the value of $n$ at maturity. The solution of equation (4) is a sigmoid curve; $k_{n}, n_{o o}$ and $n(0)$ (linear concentration of myofibre nuclei at birth) are the model input specifications (Table 1).

The rate of total protein synthesis in the steady state may be defined as the product of total ribosome number and specific rate of translation (ribosome activity) (Potapov and Elskaya, 1986). The fractional degradation rate of total protein in various species usually is $1-4 \%$ /day over the most part of the growth period, except the early postnatal stage (Lobley et al., 1980; Bates and Millward, 1981).

While there is no data in the literature concerning the in vivo activity of muscle ribosomes at various levels of energy intake, are lacking, some indirect data indicate a nonlinear dependence with a plateau at a high level of nutrition (Close and Fowler, 1985; Oltjen et al., 1986; Kita et al., 1989; Muramatsu, 1990). If the level of nutrition does not vary significantly, the activity of muscle ribosomes is relatively constant during the postnatal period (Bates and Millward, 1981; MacDonald and Swick, 1981). Furthermore, experimental data suggest a positive correlation between the rate of transcription of rDNA and translational activity of ribosomes, therefore, a similar nonlinear relationship between the activity of rDNA and level of nutrition during the postnatal period of growth seems to be very probable (Nomura et al., 1984).

In the range of feed intake above the maintenance level, the rate of muscle weight gain is determined more by the synthesis rate than by the variations in the fractional rate of degradation of structural proteins (Bates and Millward, 1981; MacDonald and Swick, 1981; Reeds and Fuller, 1983). Therefore, we suppose that the fractional rate of protein $\left(\mathrm{k}_{\mathrm{p}}\right.$, day $\left.{ }^{-1}\right)$ and rRNA $\left(\mathrm{k}_{\mathrm{r}}\right.$, day-1) degradation in the muscle during normal growth does not vary significantly by altering the level of nutrition in physiological ranges. On the other hand, during the early postnatal period of life, $\mathrm{k}_{\mathrm{p}}$ depends on time. Just after birth it declines, later becoming constant (Millward, 1978, 1980; MacDonald and Swick, 1981). There is no direct data concerning the absence of age-dependent changes of $\mathrm{k}_{\mathrm{r}}$, but some indirect data suggest that this claim is correct (Cherepanov, 1994).

The above arguments and statements define the following balance equations for total rRNA $\left(\mathrm{R}^{\wedge}, \mathrm{g}\right)$ and total protein $\left(\mathrm{P}^{\wedge}, \mathrm{g}\right)$ content in model muscle during normal postnatal growth:

$$
\begin{aligned}
& \mathrm{dR}^{\wedge} / \mathrm{dt}=\mathrm{a}_{\mathrm{d}}(\mathrm{Q}) \mathrm{D}^{\wedge}-\mathrm{k}_{\mathrm{r}} \mathrm{R}^{\wedge} \\
& \mathrm{dP}^{\wedge} / \mathrm{dt}=\mathrm{a}_{\mathrm{r}}(\mathrm{Q}) \mathrm{R}^{\wedge}-\mathrm{k}_{\mathrm{p}}(\mathrm{t}) \mathrm{P}^{\wedge},
\end{aligned}
$$

where $a_{d}$ is the activity of rDNA (g rRNA/g DNA*day); $a_{r}$ is the activity of rRNA (g protein/g rRNA*day); $k_{r}$ is the fractional degradation rate of rRNA $\left(\right.$ day $\left.^{-1}\right) ; \mathrm{k}_{\mathrm{p}}$ is the fractional degradation rate of total muscle protein $\left(\right.$ day $\left.^{-1}\right)$. 
The content of protein in muscle is approximately $20 \%$ of wet tissue. Therefore the weight of model muscle $\left(\mathrm{M}^{\wedge}, \mathrm{g}\right)$ is equal to muscle protein $\left(\mathrm{P}^{\wedge}, \mathrm{g}\right)$ multiplied by 5 , so the total weight of skeletal muscles $(\mathrm{Mm}, \mathrm{kg}$ ) can be predicted by the equation:

$$
\mathrm{Mm}=\mathrm{L}_{3} \mathrm{M}^{\wedge}=5 \mathrm{~L}_{3} \mathrm{P}^{\wedge},
$$

where $L_{3}$ is a coefficient that can be estimated empirically by comparison of predicted values of $\mathrm{M}^{\wedge}$ with experimental estimates of the weight of the muscles in the carcass at a given age (Table 1).

The relationship between the weight of the skeleton (Ms, $\mathrm{kg}$ ), weight of the muscles $(\mathrm{Mm}, \mathrm{kg})$ and the skeleton size $(\mathrm{H}, \mathrm{cm})$ for bulls and pigs can be approximated by regression (Cherepanov, 1994):

$$
\mathrm{Ms}=\mathrm{L}_{4} \mathrm{H} \mathrm{Mm}^{\mathrm{b}} \text {, }
$$

where $L_{4}$ and $b$ are empirically estimated coefficients (Table 1).

The weight of carcass (Mc, $\mathrm{kg}$ ) is the sum:

$$
\mathrm{Mc}=\mathrm{Ms}+\mathrm{Mm}+\mathrm{Fc},
$$

where $\mathrm{Fc}$ is the weight of separable fat of the carcass $(\mathrm{kg})$. At this stage of the calculation it is an unknown variable and it can be calculated by several methods. One method might be a dynamic description of preadipocyte proliferation and adipocyte volume growth in fat depots (Vogt, 1987). Body fat may be predicted also on the basis of empirical data adjusted for body condition score (Keele et al., 1992). The method used here includes calculation of $\mathrm{Fc}$ by an iteration procedure, using empirical formulae for liveweight ( $W=f(M c), k g$ ), empty body weight (Wo $=\mathrm{f}(\mathrm{W}), \mathrm{kg}$ ) and fractional content of fat in empty body weight (f, \%) (Table $\mathrm{l}$ ). The current value of $f$ depends on the age (time) and level of nutrition. The empirical equation for $\mathrm{C}(\mathrm{Q}, \mathrm{l})$ is used here in differential form:

$$
\mathrm{d} \mathrm{f} / \mathrm{dt}=\mathrm{F}\left(\mathrm{Q}, \mathrm{f}, \mathrm{f}_{\mathrm{oon}}\right)
$$

where $f_{o o}$ is the value of $f$ at maturity. The total fat content in the empty body ( $F$, $\mathrm{kg}$ ) and the weight of separable fat of the carcass ( $\mathrm{Fc}, \mathrm{kg}$ ) may be calculated using empirical formulae:

$$
\begin{aligned}
& \mathrm{F}=\mathrm{L}_{7} \mathrm{f} \text { Wo } \\
& \mathrm{Fc}=\mathrm{L}_{8} \mathrm{~F},
\end{aligned}
$$

where $L_{7}$ and $L_{8}$ are coefficients (Table 1 ). The equations (9)-(12) represent the iteration cycle. In the first iteration in equation (9) to $\mathrm{Fc}=0$, the second value of $\mathrm{Fc}$ is calculated by equation (12); it is used in the second iteration in equation (9) and so on until constant values of $\mathrm{Mc}$ and, respectively, $\mathrm{W}$ are reached. 
The total content of protein in the animal's body $(\mathrm{P}, \mathrm{kg})$ is approximately $1 / 5$ of fat-free empty body weight:

$$
\mathrm{P}=0.2(\mathrm{Wo}-\mathrm{F})
$$

Further, using the predicted values of $\mathrm{W}, \mathrm{Wo}, \mathrm{F}$ and $\mathrm{P}$ and their derivatives (daily gains) for various ages, the multiple output variables may be predicted using empirical formulae and regression relationships (energy value of daily gain, daily heat production, metabolizable energy, digestive energy, daily energy and protein requirements, etc.) (Cherepanov, 1994).

Our model is a system of five differential equations with state variables $\mathrm{H}, \mathrm{n}$, $\mathrm{P}^{\wedge}, \mathrm{R}, \mathrm{f}$ and of several functions derived from empirical data $\left(\mathrm{Mm}, \mathrm{Ms}, \mathrm{W}, \mathrm{W}_{0}\right.$ etc.). The input variable is $\mathrm{Q}$, and a set of parameters is given (Table 1). Initial values (at birth) of state variables $\mathrm{H}, \mathrm{n}, \mathrm{P}^{\wedge}, \mathrm{R}$ are $70,200,63,0.16,3$ for bulls and $18,200,5.4,0.12,1$ for pigs. The value of $\mathrm{Q}$ can be a function of time, but in our simulations the runs were performed with the same value of $\mathrm{Q}$ over a simulated age interval. In various runs $Q$ was set in physiological ranges (0.5-2.5), simulating growth at various level of nutrition.

\section{COMPARISON WITH EXPERIMENTAL DATA}

The predicted growth curves are in accordance with our and literature data (Figures 2 and 3). A numerical example illustrates the described method (Table 2). The predicted concentration of RNA in muscle does not depend significantly upon the level of nutrition. This prediction agrees with our experimental data in the

TABLE 2 The output data of model for Large White $\mathrm{x}$ Landrace pigs at parameter values given in Table $1(Q=2)$

\begin{tabular}{|c|c|c|c|c|c|c|c|c|c|c|c|c|}
\hline $\begin{array}{c}\mathrm{t}, \\
\text { day }\end{array}$ & $\begin{array}{l}\mathrm{H}, \\
\mathrm{cm}\end{array}$ & $\mathrm{n}$, & $\begin{array}{c}\mathrm{R}^{\wedge} \\
\mathrm{g}\end{array}$ & $\begin{array}{c}\mathrm{P}^{\wedge} \\
\mathrm{g}\end{array}$ & $\begin{array}{c}\mathrm{d}, \\
\mathrm{mg} / \mathrm{g}\end{array}$ & $\begin{array}{c}\mathrm{r}, \\
\mathrm{mg} / \mathrm{g}\end{array}$ & $\begin{array}{l}W^{\prime}, \\
\text { g/d }\end{array}$ & $\begin{array}{l}F^{\prime}, \\
g / d\end{array}$ & $\begin{array}{l}\text { Ps, } \\
\mathrm{g} / \mathrm{d}\end{array}$ & $\begin{array}{l}\mathrm{Pd} \\
\mathrm{g} / \mathrm{d}\end{array}$ & $\begin{array}{l}\mathrm{Pa} \\
\mathrm{g} / \mathrm{d}\end{array}$ & $\mathrm{Eff}_{\mathrm{p}}$ \\
\hline 0 & 18.0 & 200 & 0.12 & 5 & 0.460 & 4.44 & & & 1.26 & 0.38 & 0.88 & 0.70 \\
\hline 40 & 34.9 & 383 & 0.24 & 34 & 0.277 & 1.45 & 290 & 20 & 2.56 & 1.55 & 1.01 & 0.40 \\
\hline 80 & 48.9 & 629 & 0.62 & 100 & 0.214 & 1.24 & 660 & 80 & 6.51 & 4.12 & 2.39 & 0.37 \\
\hline 120 & 60.5 & 865 & 1.21 & 223 & 0.163 & 1.08 & 1030 & 220 & 12.7 & 8.99 & 3.73 & 0.29 \\
\hline 160 & 70.0 & 1030 & 1.88 & 386 & 0.130 & .97 & 1120 & 380 & 19.7 & 15.5 & 4.28 & 0.22 \\
\hline 200 & 77.9 & 1121 & 2.48 & 553 & 0.110 & .90 & 960 & 450 & 26.1 & 22.1 & 3.95 & 0.15 \\
\hline 240 & 84.3 & 1165 & 2.96 & 697 & 0.098 & .85 & 710 & 440 & 31.1 & 27.9 & 3.21 & 0.10 \\
\hline
\end{tabular}

$\mathrm{H}=$ length of carcass $(\mathrm{cm}) ; \mathrm{n}=$ mean number of muscle nuclei per $1 \mathrm{~cm}$ of myofibre length $\left(\mathrm{cm}^{-1}\right) ; \mathrm{R}^{\wedge}, \mathrm{P}^{\wedge}=$ content of RNA and protein in reference muscle, respectively $(\mathrm{g}) ; \mathrm{d}=$ concentration of DNA in reference muscle (mg DNA/g wet tissue); $r$ = concentration of RNA in reference muscle (mg RNA/g wet tissue); $\mathrm{W}^{\prime}$ = daily liveweight gain $\left(\mathrm{g} /\right.$ day); $\mathrm{F}^{\prime}=$ daily fat gain $\left(\mathrm{g} /\right.$ day); $\mathrm{Ps}=$ rate of protein synthesis in reference muscle $\left(\mathrm{Ps}=\mathrm{a}_{\mathrm{r}} \mathrm{R}^{\wedge}\right)$ $(\mathrm{g} /$ day $) ; \mathrm{Pd}=$ rate of protein breakdown $\left(\mathrm{Pd}=\mathrm{k}_{\mathrm{p}} \mathrm{P}^{\wedge}\right)(\mathrm{g} /$ day $) ; \mathrm{Pa}=$ protein accretion $(\mathrm{Pa}=\mathrm{Ps}-\mathrm{Pd})(\mathrm{g} /$ day $) ; \mathrm{Effp}=$ efficiency of protein accretion in reference muscle $(\mathrm{Effp}=\mathrm{Pa} / \mathrm{Ps})$ 

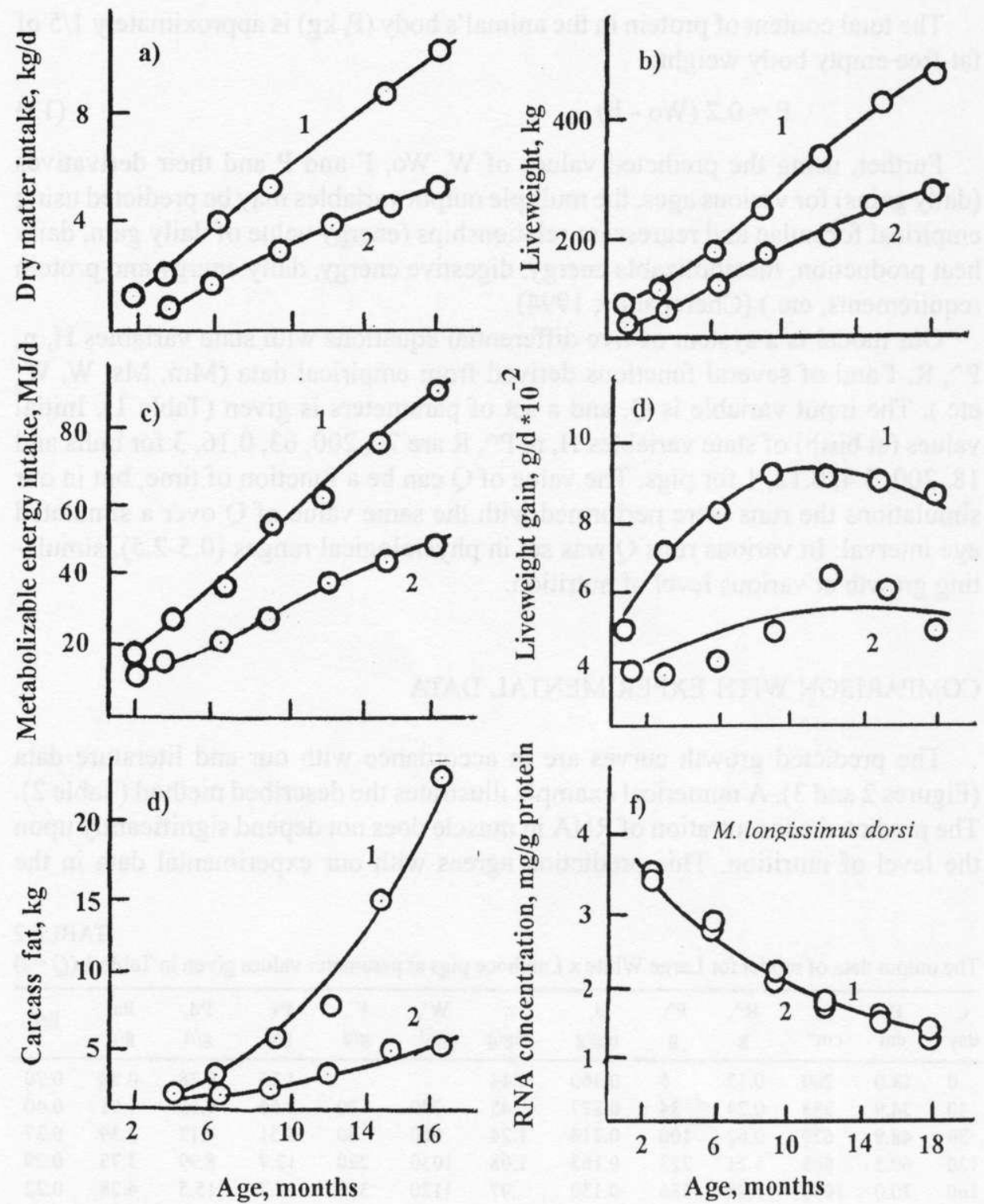

Figure 2. The growth of Black-and-White bulls at two level of nutrition. The circles are the experimental data, the lines are the predicted data. The intake of metabolizable energy was maintained during the growth at a constant level with respect to energy requirement for maintenance with multiplier x 2.1-2.3 (1) or x 1.55-1.8 (2). The concentration of RNA in M. longissimus dorsi (reference muscle in the model) depends on the time, but does not vary significantly when the level of nutrition is changed (Cherepanov, 1994) 

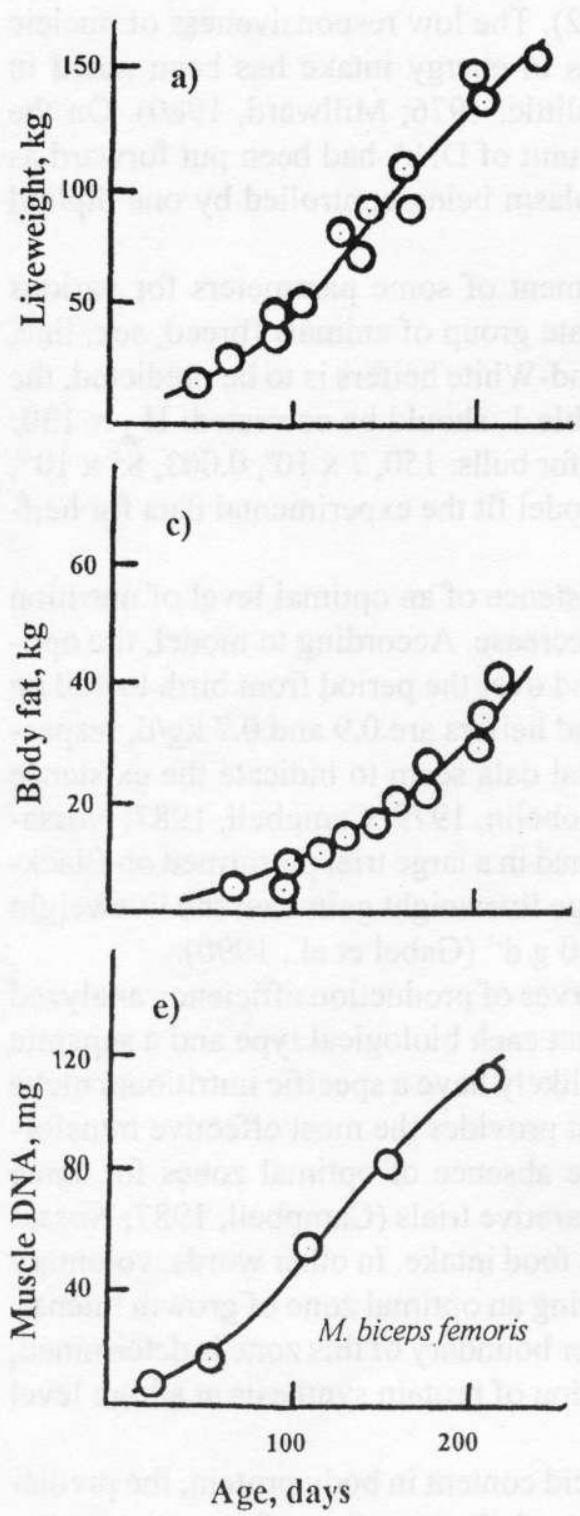

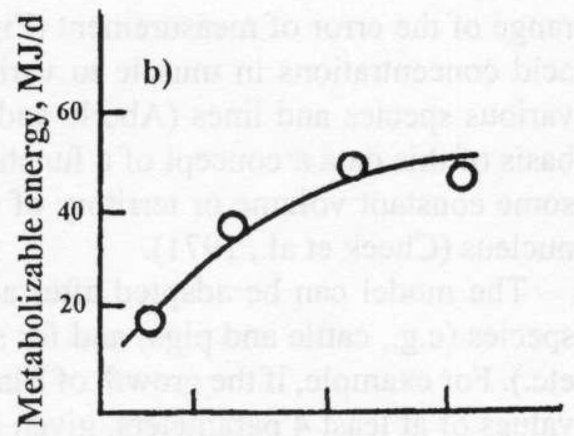

d)
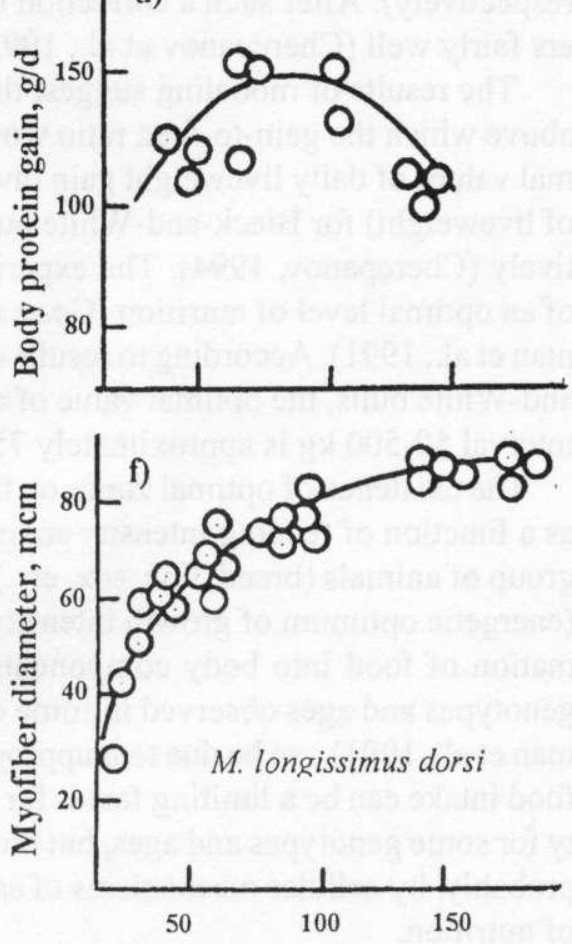

Empty body weight, $\mathrm{kg}$

Figure 3. The growth of pigs (gilts and boars, Landrace and crosses). Circles are the experimental data (a, b, c, d - Whittemore et al., 1988; e - Powell and Aberle, 1975; f - Staun, 1963). The lines are the data predicted on the model at $\mathrm{Q}=2$ ( $\mathrm{e}$ and $\mathrm{f}$ for reference muscle, for e with multiplier $\times 2.7^{-1}$ ) 
range of the error of measurement (Figure 2). The low responsiveness of nucleic acid concentrations in muscle to variations in energy intake has been noted in various species and lines (Aberle and Doolittle, 1976; Millward, 1980). On the basis of this data a concept of a functional unit of DNA had been put forward as some constant volume or territory of cytoplasm being controlled by one diploid nucleus (Cheek et al., 1971).

The model can be adapted after adjustment of some parameters for various species (e.g., cattle and pigs) and for separate group of animals (breed, sex, line, etc.). For example, if the growth of Black-and-White heifers is to be predicted, the values of at least 4 parameters, given in Table 1, should be corrected: $\mathrm{H}_{\mathrm{oo}}=130$; $\mathrm{n}_{\mathrm{oO}} \mathrm{N}=5 \times 10^{9} ; \mathrm{k}_{\mathrm{H}}=0.006 ; \mathrm{L} 6=120 \times 10^{-6}$ (for bulls: $150,7 \times 10^{9}, 0.003,85 \times 10^{-6}$, respectively). After such a correction the model fit the experimental data for heifers fairly well (Cherepanov et al., 1993).

The results of modeling suggest the existence of an optimal level of nutrition above which the gain-to-feed ratio would decrease. According to model, the optimal values of daily liveweight gain (averaged over the period from birth to $400 \mathrm{~kg}$ of liveweight) for Black-and-White bulls and heifers are 0.9 and $0.7 \mathrm{~kg} / \mathrm{d}$, respectively (Cherepanov, 1994). The experimental data seem to indicate the existence of an optimal level of nutrition (Geay and Robelin, 1979; Campbell, 1987; Nossaman et al., 1991). According to results obtained in a large trial performed on Blackand-White bulls, the optimal value of average liveweight gain over the liveweight interval $50-500 \mathrm{~kg}$ is approximately $750-950 \mathrm{~g} \mathrm{~d}^{-1}$ (Gabel et al., 1990).

The existence of optimal zones on the curves of production efficiency analyzed as a function of feeding intensity suggest that each biological type and a separate group of animals (breed, line, sex, etc.) can likely have a specific nutritional niche (energetic optimum of growth intensity) that provides the most effective transformation of food into body components. The absence of optimal zones for some genotypes and ages observed in some comparative trials (Campbell, 1987; Nossaman et al., 1991) can be due to inappropriate food intake. In other words, voluntary food intake can be a limiting factor for entering an optimal zone of growth intensity for some genotypes and ages, but the upper boundary of this zone is determined, probably, by cellular mechanisms of saturation of protein synthesis at a high level of nutrition.

Using existing data about mean amino acid content in body protein, the predicted total protein gain may be converted into daily accretion of essential amino acids and then, using concept of "ideal protein", into daily individual amino acid requirements for a given time period and level of nutrition. The detailed description of this and other possible in which this model can be applied is beyond the scope of this paper. 


\section{CONCLUSIONS}

The optimal growth rate and nutrient requirements (energy and protein) for various ages can be predicted on the basis of a model for various biological types and separate groups of animals on the condition that the values of morphophysiological parameters for these animals are known, i.e. $\mathrm{H}_{\mathrm{oc}}$ (proliferative potential of germinal cells in epiphyseal plates), $\mathrm{N}$ (muscle cellularity), $\mathrm{k}_{\mathrm{p}}$ (stability of muscle protein), $L_{6}$ (rate of fat tissue maturation), etc. The methods needed to estimate the values of these parameters in vivo are yet to be developed. They can include serial measurements of linear growth, $N^{\tau}$-methylhistidine and creatinine excretion, ultrasound methods, magnetic resonance imaging, etc. As more experimental data is accumulated, the concepts and modeling approach described above will provide a rational framework for the development of such predictive tools.

\section{REFERENCES}

Aberle E.D., Doolittle D.P., 1976. Skeletal muscle cellularity in mice selected for large body size and in controls. Growth 40, 133-145

Alberghina F.A., 1975. A model for the regulation of growth in mammalian cells. J. Theor. Biol. 55, 533-545

Allen R.E., Merkel R.A., Young R.B., 1979. Cellular aspects of muscle growth: myogenic cell proliferation. J. Anim. Sci. 49, 115-127

Bates P.C., Millward D.J., 1981. Characteristics of skeletal muscle growth and protein turnover in a fast-growing strain. Brit. J. Nutr. 46, 7-13

Brown J.E., Brown C.J., Butts W.T., 1972. A discussion of the genetic aspects of mature weight and rate of maturation in Hereford and Angus cattle. J. Anim. Sci. 34, 525-537

Burleigh I.G., 1974. On the cellular regulation of growth and development. Biol. Rev. 49, 267- 320

Campbell R.G., 1987. Energy and protein metabolism in the pig. In: Manipulating Pig Production. Proceedings of the Inaugural Conference of the Australian Pig Association, Werribe (Australia), pp. $85-96$

Campion D.R., Richardson R.L., Reagan J.O., Kraeling R.R., 1981. Changes in the satellite cell population during postnatal growth of pig skcletal muscle. J. Anim. Sci. 52, 1014-1023

Campion D., 1987. The muscle satellite cell: a review. Int. Rev. Cytol. 87, 225-251

Cheek D., Hill D.E., 1970. Muscle and liver cell growth: role of hormones and nutritional factors. Fed. Proc. 29, 153-159

Cheek D., Holt A.B., Hill E., Talbert J.I., 1971. Skeletal muscle cell mass and growth: the concept of the deoxyribonucleic acid unit. Pediat. Res. 5, 312-328

Cherepanov G.G., 1994. System morphophysiological theory of animal growth (in Russian). Obninsk - Borovsk (Russia), pp. 104

Cherepanov G.G., Agaphonov V.I., Rechetov V.B., 1993. Modification of a system morpho-physiological model for predicting cattle growth in view of sexual dimorphism (in Russian). Selskokhoz. Biol. 2, 14-21 
Close W.H., Fowler W.R., 1985. Energy requirements of pigs. In: D.J.A. Cole, W. Haresign (Editors). Recent Developments in Pig Nutrition. Nottingham University Press, Nottingham (UK), pp. 4-17

Gabel M., Poppe S., Grosse F., Papstein H.-J., 1990. Einflus der Futterungsintensität auf die Mastleistungen und den Schlachtkörperwert von Mastrindern. Wiss. Z. Univ. Rostock. N- Reihe 39 (8), 158-165

Geay Y., Robelin J., 1979. Variation of meat production capacity in cattle due to genotype and level of feeding: genotype - nutrition interaction. Livest. Prod. Sci. 6, 263-276

Keele J.W., Williams C.B., Bennett G.L., 1992. A computer model for predict the effects of level of nutrition on composition of empty body gain in beef cattle. I. Theory and development. J. Anim. Sci. 70, 841-857

Kember N.F., 1982. Cell kinetics of cartilage. In: B.K. Hall (Editor). Cartilage 1, 149-180

Kita K., Muramatsu T., Tasaki I., Okumura J., 1989. Influence of dietary non-protein energy intake on whole body protein turnover in chicks. Brit. J. Nutr. 61, 235-244

Kitiyakara A., Angevine D.N., 1963. A study of the pattern of post-embryoe growth of M. gracilis in mice. Develop. Biol. 8, 322-340

Lobley G.E., Milne V., Lovine J.M., Reeds P.J., Penne K., 1980. Whole body and tissue protein synthesis in cattle. Brit. J. Nutr. 43, 491-502

Mac Donald M.L., Swick R.W., 1981. The effect of protein depletion and repletion on muscle protein turnover in the chick. Biochem. J. 194, 811-819

Millward D.J., 1978. The regulation of muscle protein turnover in growth and development. Biochem. Soc. Trans. 6, 494-499

Millward D.J., 1980. Protein turnover in skeletal and cardiac muscle during normal growth and hypertrophy. In: K. Widenthal (Editor). Degradative Processes in Heart and Skeletal Muscle. Amsterdam, pp. 161-199

Muramatsu T., 1990. Nutrition and whole-body protein turnover in the chicken in relation to mammalian species. Nutr. Res. Rev. 3, 211-228

Nomura M., Gourse R., Bayghman G., 1984. Regulation of the synthesis of ribosomes and ribosomal components. Ann. Rev. Biochem. 53, 75-117

Nossaman D.A., Schinkel A.P., Miller L.F., Mills S.F., 1991. Interaction of somatotropin and genotype on the requirement for energy in two lines of finishing pigs. J. Nutr. 121, 223-230

Oltjen J.W., Bywater A.C., Baldwin R.L., Garrett W.N., 1986. Development of a dynamic model of beef cattle growth and composition. J. Anim. Sci. 62, 86-97

Potapov A.P., Elskaya A.W., 1986. Translation of natural mRNA. 1. Kinetic analysis of translation of one type of mRNA (in Russian). Biopolim. Cell 2, 88-92

Powell S.E., Aberle E.D., 1975. Cellular growth of skeletal muscle in swine differing in muscularity. J. Anim. Sci. 40, 476-485

Reeds P.J., Fuller M.F., 1983. Nutrient intake and protein turnover. Proc. Nutr. Soc. 42, 463-471

Soboleva T.K., Oddy V.H., Pleasants A.B., Oltjen J.W., Ball A.J., McCall D.G., 1999. A dynamic model of body composition in sheep. Proc. N.Z. Soc. Anim. Prod. 59, 275-278

Staun H., 1963. Various factors affecting number and size of muscle fibers in the pig. Acta Agr. Scand. 13, 293-322

Swatland H.J., 1977. Accumulation of myofiber nuclei in pigs with normal and arrested development. J. Anim. Sci. 44, 759-764

Vogt J., 1987. Entwicklung eines Simulationsmodelles zur Beschreibung der Wachstumsdynamik des Fettgewebes. Dissertation, University Hohenheim (Germany)

Whittemore C.T., Tullis J.B., Emmans G., 1988. Protein growth in pigs. Anim. Prod. 46, 437- 445

Williams P.E., Goldspink G., 1971. Longitudinal growth of striated muscle fibers. J. Cell Sci. 9, 751767 


\section{STRESZCZENIE}

\section{Zalożenia morfofizjologiczne i model wzrostu zwierząt}

W oparciu o uprzednio sprawdzone założenia biologiczne zaproponowano model wzrostu pourodzeniowy zwierząt gospodarskich. Założono istnienie dwóch głównych procesów - rozrostu komórek płytek wzrostowych kości i zwiększenie liczby jąder w tkance mięśni szkieletowych oraz przyjęto, że podstawowe kinetyczne wskaźniki metabolizmu RNA i białka w mięśniach poprzecznie prążkowanych pozostają niezmienione (względnie stałe) od wczesnego okresu po narodzeniu do dojrzałości.

Masę tkanki mięśniowej kośćca oszacowano na podstawie dynamicznego sub-modelu, a ciężar kośćca, tuszy i masy ciała obliczono przy pomocy równań regresji. W odniesieniu do zwierząt gospodarskich model dokładnie zgadzał się z danymi doświadczalnymi i pozwalał na stwierdzenie, że każdy typ biologiczny i grupa zwierząt (masa, płeć, linia, itd.) ma optymalny okres intensywnego wzrostu, podczas którego zachodzi najbardziej wydajne przetwarzanie pokarmu w składniki ciała.

W podsumowaniu zaproponowano kierunki dalszych badań i zasugerowano ewentualne znaczenie dla praktyki. 